Equalita, Vol. 1 Issue 1, Agustus 2019

Avaliable online at http://syekhnurjati.ac.id/jurnal/index.php/equalita/article/view/5161

Diterbitkan oleh Pusat Studi Gender dan Anak LP2M IAIN Syekh Nurjati Cirebon, Indonesia

\title{
ANALISIS TUMBUH KEMBANG ANAK DITINJAU DARI ASPEK PERKEMBANGAN MOTORIK KASAR ANAK USIA DINI
}

\author{
Aip Saripudin \\ IAIN Syekh Nurjati Cirebon
}

asaripudin@syekhnurjati.ac.id

- Received: 25 Juni 2019 •Accepted: 03 Agustus 2019 •Published online: 30 Agustus 2019

Abstract: The golden age of the humans is going on since a child was born until the age of eight years. In this case the growth and development of kids drove rapidly, so it needs an effective stimulation of parents and their environment. The growth is quantitative changes that happen to people in terms of the growing number and size of, the dimensions on a cellular level as well as organ which occurs on any individual. Temporary out growth qualitative which the process that refers to the improvement of social and psychological people and going on all his life human. In aspects of the development of early childhood, rough motor there will be growth and child development sustainable. Of course, hand in hand growth and development to the various aspects of an early age will walk in accordance with, phases of his age so parents need to have a comprehensive knowledge about various aspects in early childhood.

\section{Key Word: Growth and development, rough motor, early childhood}

\begin{abstract}
Abstrak: Masa golden age pada manusia terjadi sejak anak dilahirkan hingga usia delapan tahun. Pada masa ini pertumbuhan dan pekembangan anak melaju pesat, sehingga perlu stimulasi yang efektif dari orang tua dan lingkungannya. Pertumbuhan merupakan perubahan yang bersifat kuantitatif yang terjadi pada manusia dalam hal bertambahnya jumlah dan ukuran, dimensi pada tingkat sel serta organ yang terjadi pada setiap individu. Sementara perkembangan yakni proses kualitatif yang mengacu pada penyempurnaan fungsi-fungsi sosial dan psikologis dalam diri seseorang dan berlangsung sepanjang hidupnya manusia. Dalam aspek perkembangan motorik kasar anak usia dini, maka akan terjadi pertumbuhan dan perkembangan anak secara berkesinambungan. Tentunya secara beriringan, pertumbuhan dan perkembangan berbagai aspek pada anak usia dini akan berjalan sesuai dengan tahapan usianya, sehingga orang tua perlu memiliki pengetahuan yang menyeluruh tentang berbagai aspek pada anak usia dini.
\end{abstract}

\section{Kata Kunci: Tumbuh kembang, motorik kasar dan anak usia dini}

\section{A. PENDAHULUAN}

Undang-undang Nomor 20 Tahun 2003 tentang Sistem Pendidikan Nasional telah mengamanatkan dilaksanakannya penndidikan kepada seluruh rakyat Indonesia sejak usia dini, yakni sejak anak dilahirkan (Depdiknas, Undang-Undang N0.20 Tentang Sisdiknas, 
Aip Saripudin

2003). Proses pembelajaran PAUD hendaknya dilakukan dengan tujuan memberikan makna bagi anak melalui pengalaman nyata. Pengalaman nyata anak yang memungkinkan anak menunjukkan aktifitas dan rasa ingin tahu secara optimal dan menempatkan posisi pendidik sebagai pendamping yang selalu dekat dengan anak dalam berbagai kegiatan pembelajaran. Namun tentunya peran orang tua juga sangat penting posisinya. Selain berperan sebagai orang tua, tentunya peran mendidik, peran sosial, peran afektif juga harus selalu hadir dengan anak. Orang tua hendaknya tidak menyerahkan sepenuhnya proses tumbuh kembang anak kepada sekolah. Hanya proses sosialisasi anak dengan lingkungan sekolah yang memungkinkan lebih banyak terjadi di sekolah. Tentunya melalui proses pendidikan di sekolah diharapkan dapat menghindari bentuk pembelajaran yang berorientasi pada kehendak guru yang menempatkan anak secara pasif dan guru menjadi dominan dalam segala urusan. Dalam lokakarya pendampingan PAUD di Fakultas Psikologi UGM, Sumirah mengatakan bahwa "PAUD diajarkan melalui cara bermain, dengan begitu tidak akan merampas haknya. Semua itu untuk melejitkan semua potensi anak dari motorik, bahasa, kognitif, emosional, dan sosial dengan mengedepankan kebebasan memilih, merangsang kreatifitas dan merangsang karakter."

Pada masa anak usia dini anak mengalami masa keemasan (the golden years) yang merupakan masa anak mulai peka atau sensitif untuk menerima berbagai rangsangan.masa peka pada masing - masing anak berbeda seiring dengan laju pertumbuhan dan perkembangan anak secara individual. Masa peka adalah masa terjadinya kematangan fungsi fisik dan psikis yang siap merespons stimulasi yang diberikan oleh lingkungan. Masa ini juga merupakan masa peletak dasar untuk mengembangkan kemampuan kognitif, motorik, bahasa, sosio-emosional, agama, seni dan moral anak. Pendidikan usia dini merupakan wahana pendidikan yang sangat fundamental dalam memberikan kerangka dasar terbentuk dan berkembangnya dasar dasar pengetahuan, sikap dan keterampilan pada anak. Keberhasilan proses pendidikan pada masa initersebut menjadi dasar untuk proses pendidikan selanjutnya. Keberhasilan penyelenggaraan pendidikan pada lembaga pendidikan anak usia dini, seperti kelompok bermain, taman penitipan anak, satuan padu sejenis maupun taman kanak-kanak sangat tergantung padasistem dan proses pendidikan yang dijalankan.

Banyak hal yang bisa meningkatkan perkembangan anak ketika ia mengalami proses belajar yang menyenangkan, salah satunya adalah perkembangan motorik baik motorik halus maupun motorik kasara anak.

\section{KONSEP PENDIDIKAN ANAK USIA DINI}

Berdasarkan Undang-undang Nomor 20 Tahun 2003 tentang Sistem Pendidikan Nasional berkaitan dengan Pendidikan Anak Usia Dini tertulis pada Pasal 28 Ayat 1 yang berbunyi "pendidikan anak usia dini diselenggarakan bagi anak sejaklahir sampai dengan 


\section{Aip Saripudin}

enam tahun dan bukan merupakan prasayarat untuk mengikuti pendidikan dasar. Pendidikan anak usia dini merupakan salah satu bentuk penyelenggaraan pendidikan yang menitik beratkan pada peletakan dasar arah pertumbuhan dan perkembangan fisik (kordinasi motoorik halus dan kasar), kecerdasan (daya pikiran, daya cipta, kecerdasan emosi, kecerdasan spiritual), sosial emosional (sikap dan perilaku sertaberagama), bahasa dan komunikasi, sesuai denan keunikan dan tahap-tahap perkembangan yang dilalui anak usia dini.

Pengertian lain menjelaskan bahwa pendidikan anak usia dini adalah pemberian upaya untuk menstimulasi, membimbing, mengasuh dan pemberian kegiatan pembelajaran yang akan menghasilkan kemampuan dan keterampilan anak. Pendidikan anak usia dini merupakan sebuah pendidikan yang dilakukan pada anak yang baru lahir sampaidengan delapan tahun.

\section{Prinsip-prinsip Perkembangan Anak Usia Dini}

Beberapa prinsip yang perlu diperhatikan dalam pelaksanaan kegiatan pembelajaran pada pendidikan anak usia dini meliputi berorientasi pada perkembangan anak, berorientasi pada kebutuhan anak, bermain sambil belajar atau belajar seraya bermain, stimulasi terpadu, lingkungan kondusif, menggunakan pendekatan tematik, Aktif, Kreatif, Inovatif, dan Menyenangkan, Menggunakan berbagai meia dan sumber belajar, Mengembangkan kecakapan hidup serta Pemanfaatan teknologi informasi (Yuliani, 2010). Secara berurutan akan dijelaskan sebagai berikut:

a. Berorientasi pada perkembangan anak

Dalam melakukan kegiatan, pendidik erlu memberikan kegiatan yang sesuai dengan perkembangan tahapan anak. Anak merupakan individu yang unik, maka perlu memperhatikan perbedaan secara individual. Dengan demikian dalam kegiatan yang disiapkan perlu diperhatikan cara belajar anak yang dimulai dari cara sederhana ke rumit, kongkret ke abstrak, gerakan ke verbal, dank e aku-an ke rasa sodial.

b. Berorientasi pada kebutuhan anak

Anak pada usia dini sedang membutuhkan proses belajar untuk mengoptimalkan semua aspek perkembangannya. Dengan demikian berbagai jenis kegiatan pembelajaran hendaknya dilakukan berdasarkan pada perkembangan dan kebutuhan masing-masing anak.

c. Bermain sambil belajar atau belajar seraya bermain.

Bermain merupakan pendekatan dalam pelaksanaan pembelajaran pada anak usia dini. Kegiatan pembelajaran yang disiapkan oleh pendidik hendaknya dilakukan dalam situasi yang menyenangkan dengan menggunakan strategi, metode, materi atau bahan, dan media yang menarik serta mudah diikuti oleh anak. Melalui bermain anak diajak untuk berekplorasi, menemukan dan memanfaatkan objek-objek yang dekat dengan 


\section{Aip Saripudin}

anak,sehingga pembelajaran menjadi bermakna bagi anak.ketika bermain anak membangun pengertian yang berkaitan dengan pengalamannya.

d. Stimulasi terpadu

Pengembangan anak bersifat sistematis, progresif dan bersifat kesinambungan antara aspek kesehatan, gizi dan pendidikan. Hal ini berarti kemajuan perkembangan satu aspek akan mempengaruhi aspek perkembangan lainnya. Karakteristik anak memandang sesuatu sabgaai suatu keseluruhan, bukan bagian demi bagian. Stimulasi harus diberikan secara terpadu sehingga seluruh aspek perkembangan dapat berkembangan secara berkelanjutan dengan memperhatikan kematangan dan konteks sosial, dan budaya setempat.

e. Lingkungan kondusif

Lingkungan pembelajaran harus dicipakan sedemikian menarik dan menyenangkan serta demokratis sehingga anak merasa aman, nyaman dan meyenangkan dalam lingkungan bermain baik didalam maupun diluar ruangan. Penataan ruang belajar harus disesuaikan dengan ruang gerak anak dalam bermain sehingga anak dapat berinteraksi dengan mudah baik dengan pendidik maupun dengan temannya.

f. Menggunakan pendekatan tematik

Tema sebagai wadah mengenalkan berbagai konsep untuk mengenal dirinya an lingkungan sekitarnya. Tema dipilih dan dikembangkan dari hal yang paling dekat dengan anak, sederhana, serta menarik minat.

g. Aktif, Kreatif, Inovatif, dan Menyenangkan

Proses pembelajaran yang aktif, kreatif, iovati dan menyenangkan dapat dilakukan oleh anak yang disiapkan oleh pendidik melalui kegiatan-kegiatan yang menarik, menyenangkan untuk, membangkitkan rasa ingin tahu anak, memotivasi anak untuk berfikir kritis, dan menemukan hal-hal baru.

h. Menggunakan berbagai meia dan sumber belajar

Setiap kegiatan untuk menstimulasi perkembangan potensi anak, perlu memanfaatkan berbagai media dan sumber belajar, antara lain dilingkungan alam sekitar atau bahan-bahan yang sengaja disiapkan oleh pendidik.

i. Mengembangkan kecakapan hidup

Proses pembelajaran harus diarahkan untuk mengembangkan kecakapan hidup melalui penyiapan lingkungan belajar menunjang berkembangnya kemampuan menolong diri sendiri, disiplin dan sosialisasi serta memperoleh keterampilan dasar yang berguna untuk kelangsungan hidupnya.

j. Pemanfaatan teknologi informasi 
Aip Saripudin

Pelaksanaan stimualsi pada anak usia dini dapa memanfaatkan teknologi untuk kelancaran kegiatan, misalnya tape, radio, televisi, komputer. Pemanfaatan teknologi informasi dalam kegiatan pembelajaran dimaksudkan untuk mendorong anak menyenangi belajar.

\section{Tahapan Perkembangan Anak Usia Dini}

Secara umum aspek perkembangan anak usia dini terdiri dari aspek kognitif, bahasa, motorik, seni, sosial emosional serta moral agama (Mursyid, 2015). Adapun penjelasan secara singkat dapat diuraikan sebagai berikut:

Pada Aspek kognitif prasekolah sudah berkembang dengan baik. Ditandai dengan kemampuan mengenali kata dengan suara yang serupa, sudah bisa berhitung sampai 20, sudah memahami urutan kejadian sehari-hari meski belum terlalu paham konsep waktu seperti tadi, sekarang atau kemarin. Pada usia ini anak juga sudah mampu bermain puzzle dan memasangkannya dengan sesuai. Dan diusia 5 tahun, dengan rangsangan dan stimulasi yang diberikan oleh guru maupun orantua, kemampuan mereka semakin bertambah. Bisa menghitung sampai 50, mulai tertarik dan paham angka dan huruf, dan menunjukkan ketertarikannya untuk belajar.

Pada aspek perkembangan bahasa Anak usia 4 tahun sudah mahir dalam berbahasa. Mereka sudah bisa menggunakan struktur kalimatyang rumit dan menggunakan keterangan waktu. Dan mereka sudah mampu mengekspresikan wajah dan nada suara. Berbisik, merajuk, berteriak maupun menyanyilagu kesukaan mereka dengan lancar. Sedangkan saat usia mereka 5 sampai 6 tahun, mereka sudah mahir menceritakan kejadian yang dialami, paham lelucon, dan sering melontarkan humor-humor ringan. Mereka juga sudah paham akan orang-orang terdekatnya.

Aspek Fisik/Motorik yang paling menonjol dari usia ini adala nafsu makannya yang meningkat. Karena diusia ini kebutuhan kalori mereka meningkat seiring dengan perkembangan isik dan otak mereka. Rata-rata perharinya mereka membutuhkan 1700-1800 kalori. Sedangkan untuk motoriknya, ada beberapa hal yang sudah mereka bisa lakukan, diantaranya: (1) Mampu berdiri diatas satu kaki, (2) Berjalan maju diatas garis lurus, (3) Mahir menaiki tangga, (4) melompat dengan ketinggian 15-30 cm, (5) Melempar dan menangkap bola dengan baik, (6) Memegang pensil dengan sempurna, (7) Menulis beberapa huruf dan angka, (8) Kemampuan tangan yang semakin terampil.

Pada Aspek Sosial-emosional diusia prasekolah anak sangat senang bermain diluar rumah, bertemu dengan teman baru dan berteman dengan mereka. Meski belum terlalu intens dalam bermain bersama dan masih sering berubah-ubah, tapi mereka sudah cukup baik jika bermain dan bekerja kelompok. Dan mereka sudah mulai memilih teman dekat dan sahabat merea. Pada usia 5-6 tahun, anak sudah benar-benar memilih sahabat untuk dirinya. Dalam 
Aip Saripudin

bermain dan bekerja kelompok pun mereka sudah tidak malu-malu lagi dalam menunjukkan ide dan pertisipasinya. Meeka mampu menghibur orang lain dan sudah ada keinginan dalam dirinya terlihat menonjol dan berprestasi.

\section{KONSEP PERKEMBANGAN MOTORIK}

Perkembangan motorik diartikan sebagai perkembangan dari unsur kematangan pengendalian gerak tubuh dan otak sebagai pusat gerak. Gerakan ini secara jelas dibedakan menjadi gerak kasar dan halus. Keadaan sekitar sangat berpengaruh terhadap peningkatan kemampuan motorik anak, terutama lingkungan keluarga. Selain itu perkembangan motorik juga berarti perkembangan gerak pengendalian jasmaniah melalui kegiatan pusat syaraf, urat syaraf dan otot-otot yang terkoordinasi (Hurlock, 1978). Menurut Endang Rini Sukamti (Sukamti, 2007) menyatakan bahwa perkembangan motorik adalah suatu proses kemasakan atau gerakan yang langsung melibatkan otot-otot untuk bergerak dan proses pensyarafan yang menjadikan seseorang mampu menggerakkan tubuhnya. Pengertian yang senada juga dikemukakan oleh B. Suhartini dan Sumarjo (2000) bahwa perkembangan motorik berarti perkembangan pengendalian gerakan jasmaniah melalui kegiatan syaraf, urat syaraf dan otot yang terkoordinasi. Perkembangan motorik anak diketahui dengan adanya bentuk-bentuk keterampilan motorik yang sama pada anak-anak, dalam kelompok umur yang sama memperlihatkan hal yang sama juga. (Suyanto, 2005) menyatakan bahwa aspek perkembangan anak meliputi fisik motorik, intelektual, moral, emosional, sosial, bahasa dan kreativitas.

Menurut Gasell dan Ames, dan Illingsworth dalam Slamet Suyanto, 2003), menyatakan bahwa perkembangan motorik pada anak mengikuti delapan pola umum:

a. Continuity (bersifat kontinyu), dimulai dari yang sederhana ke yang kompleks sejalan dengan bertambahnya usia.

b. Uniform sequence (memiliki tahapan yang sama) yaitu memiliki pola tahapan yang sama untuk semua anak, meskipun kecepatan pada tiap anak berbeda.

c. Maturity (kematangan) yaitu dipengaruhi oleh perkembangan sel syaraf. Sel syaraf telah terbentuk semua saat anak lahir, tetapi proses mielinasinya masih terus berlangsung sampai beberapa tahun kemudian. Anak tidak dapat melakukan gerakan tertentu yang terkoordinasi sebelum proses mielinasi tercapai.

d. Umum ke khusus, yaitu dimulai dari gerak yang bersifat umum ke gerak yang bersifat khusus. Gerakan secara menyeluruh dari badan terjadi lebih dulu sebelum gerakan bagianbagiannya. Hal ini disebabkan karena otot-otot halus (fine muscles).

e. Dimulai gerak refleks bawaan ke arah gerak yang terkoordinasi. Anak lahir di dunia telah memiliki refleks, seperti menangis bila lapar, haus, sakit atau merasa tidak enak. Refleks 
Aip Saripudin

tersebut akan berubah menjadi gerak yang terkoordinasi dan bertujuan.

f. Bersifat chepalo-caudal direction artinya bagian yang mendekati kepala berkembang lebih dulu dari bagian yang mendekati ekor. Otot leher berkembang lebih dulu daripada otot bagian kaki.

g. Bersifat proximo-distal, artinya bahwa bagian yang mendekati sumbu tubuh yaitu tulang belakang berkembang lebih dulu dari bagian yang lebih jauh. Otot dan syaraf lengan berkembang lebih dulu dari otot jari. Oleh karena itu anak TK menangkap bola dengan lengan bukan dengan ibu jari.

h. Koordinasi bilateral menuju crosslateral, artinya bahwa koordinasi organ yang sama berkembang lebih dulu sebelum bisa melakukan koordinasi organ bersilangan.

Gallahue (Hidayanti, 2013) mengemukakan bahwa kemampuan motorik kasar sangat berhubungan dengan kerja otot-otot besar pada tubuh manusia. Kemampuan ini biasanya digunakan oleh anak untuk melakukan aktivitas olahraga. Kemampuan ini berhubungan dengan kecakapan anak dalam melakukan berbagai gerakan. Gallahue membagi kemampuan motorik dalam tiga kategori yaitu: Kemampuan Lokomotor adalah kemampuan yang digunakan untuk memerintahkan tubuh dari suatu tempat ke tempat yang lain. Seperti berjalan, berlari, melompat, dan meluncur. Kemampuan Non Lokomotor adalah kemampuan yang digunakan tanpa memindahkan tubuh atau gerak ditempat. Contoh gerakan kemampuan non-lokomotor adalah menekuk dan meregang, mendorong dan menarik, jalan di tempat, loncat ditempat, berdiri dengan satu kaki, dan mengayuhkan kaki secara bergantian. Kemampuan Manipulatif adalah kemampuan yang dikembangkan saat anak sedang menguasai berbagai macam objek dan kemampuan ini lebih banyak melibatkan tangan dan kaki. Contohnya adalah gerakan melempar, memukul, menendang, menangkap objek, memutar tali, dan memantulkan atau menggiring bola.

\section{Fungsi Perkembangan Motorik bagi Anak}

Perkembangan keterampilan motorik merupakan faktor yang penting bagi perkembangan pribadi secara keseluruhan. Hurlock (1978) mencatat beberapa alasan tentang fungsi perkembangan motorik bagi konstelasi perkembangan individu, yaitu: Melalui keterampilan, motorik anak dapat menghibur dirinya dan memperoleh perasaan senang, seperti anak merasa senang dengan memiliki keterampilan memainkan boneka, melempar, dan menangkap bola atau memainkan alat-alat permainan. Melalui keterampilan, motorik anak dapat beranjak dari kondisi "helplessness" (tidak berdaya) pada bulan-bulan pertama kehidupannya, kek kondisi yang independence" (bebas, tidak bergantung). Anak dapat bergerak dari satu tempat ke tempat lain dan dapat berbuat sendiri untuk dirinya. Kondisi ini akan menunjang perkembangan "self confidence" (rasa percaya diri). Melalui keterampilan 
Aip Saripudin

motorik, anak dapat menyesuaikan dirinya dengan lingkungan sekolah (school adjustment). Pada usia pra sekolah (Taman Kanak-kanak) atau usia kelas-kelas awal Sekolah Dasar, anak sudah dapat dilatih menulis, menggambar, melukis, dan baris berbaris. Melalui perkembangan motorik yang normal memungkinkan anak dapat bermain atau bergaul dengan teman sebayanya, sedangkan yang tidak normal akan menghambat anak untuk dapat bergaul dengan teman sebayanya bahkan dia akan terkucil atau menjadi anak yang fringer (terpinggirkan).

Departemen pendidikan dan kebudayaan (Depdiknas, 2008) menjabarkan fungsi pengembangan motorik sebagai berikut : 1) Melatih kelenturan otot jari dan tangan, 2) Memacu pertumbuhan dan pengembangan fisik motorik, rohani dan kesehatan anak, 3) Membentuk, membangun dan memperkuat tubuh anak, 4) Melatih keterampilan atau ketangkasan gerak dan berpikir anak, 5) Meningkatkan perkembangan emosional anak, 6) Meningkatkan perkembangan sosial anak, 7) menumbuhkan perasaan menyenangi dan memahami manfaat kesehatan pribadi.

Banyak ahli yang menjelaskan tentang pentingnya meningkatkan perkembangan motorik anak usia dini yakni dalam mengembangkan fisiologis anak, memacu perkembangan sosial emosional anak serta meningkatkan kemampuan kognitif anak usia dini. Peran kemampuan motorik untuk perkembangan fisiologis anak yakni Anak bergerak atau berolahrga akan menjaga anak agar tidak mendapat masalah dengan jantungnya karena sering dan rutinnya anak bergerak dengan cara berolahraga maka kegiatan tersebut juga menstimulasi semua proses fisiologis anak seperti peningkatan sirkulasi darah dan pernapasannya. Kegiatan motorik kasar anak merupakan awal anak mulai kenal kegiatan berolahraga. Jika anak terbiasa berolahraga mulai ia kecil maka hal itu akan berakibat baik untuk pembentukan postur tubuh anak kemudian. Selain itu, kegiatan berolahraga atau bergerak akan membuat tulang dan otot anak bertambah kuat.

Peran kemampuan motorik untuk perkembangan sosial dan emosional anak yakni seorang anak yang mempunyai kemampuan motorik yang baik akan mempunyai rasa percaya diri yang besar. Lingkungan teman-temannya pun akan menerima anak yang memiliki kemampuan mptorik atau gerak lebih baik, sedangkan anak yang tidak memiliki kemampuan gerak tertentu akan kurang diterima teman-temannya. Penerimaan teman-teman dan lingkungannya akan menyebabkan anak mempunyai rasa percaya diri yang baik. Oleh sebab itu, sebaiknya saat anak-anak kecil mereka dapat mulai mempelajari berbagai jenis kegiatan fisik motorik secara bebas sesuai dengan kemampuan mereka sendiri dan tanpa disbandingbandingkan dengan anak lainnya. Hal itu membuat anak mau melakukan berbagai kegiatan dengan senang hati tanpa rasa takut dan malu. 
Peran kemampuan motorik untuk kognitif anak yakni meningkatnya kemampuan fisik anak saat mereka di usia RA membuat aktivitas fisik motorik mereka juga semakin banyak. Segala kegiatan anak selalu dilakukan dengan bermain. Bermain akan meningkatkan aktivitas fisik anak. Maxim (1993), menyatakan bahwa aktivitas fisik akan menciptakan pula rasa keingintahuan anak dan membuat anak-anak akan memperhatikan benda-benda, menangkapnya, mencobanya, melemparkannya atau menjatuhkannya, mengambil, mengocokngocok, dan meletakkan kembali benda-benda ke dalam tempatnya. Adanya kemampuan atau keterampilan motorik anak juga akan menumbuhkan kreativitas dan imajinasi anak yang merupakan bagian dari perkembangan mental anak (Sujiono, 2005).

Pentingnya perkembangan motorik anak usia dini dalam meningkatkan penguasaan keterampilan yang tergambar dalam kemampuan menyelesaikan tugas motoric tertentu. Kualitas motorik terlihat dari seberapa jauh anak tersebut mampu menampilkan tugas motorik yang diberikan dengan tingkat keberhasilan tertentu. Jika tingkat keberhasilan dalam melaksanakan tugas motorik tinggi berarti motorik yang dilakukan efektif dan efisien.

\section{Perkembangan Motorik Kasar}

Bambang sujiono (2007), menyatakan bahwa gerakan Motorik Kasar adalah kemampuan yang membutuhkan kordinasi sebagian besar bagian tubuh anak. Gerakan Motorik Kasar melibatkan aktivitas otot-otot besar seperti otot tangan, otot kaki, dan seluruh tubuh anak.perkembangan motorik kasar anak lebih dulu dari pada perkembangan motorik halus, misalnya anak akan lebih dulu memegang benda-benda yang ukuran besar dari pada yang ukuran kecil. Karena anak belum mampu mengontrol gerakan jari-jari tangannya untuk kemampuan motorik halusnya, seperti meronce, menggunting dan lain-lain. Gerak motorik kasar terbentuk saat anak mulai memiliki kordinasi dan keseimbangan hamper seperti orang dewasa. Gerakan motorik kasar merupakan kemampuan yang membutuhkan koordinasi sebagian besar tubuh anak. Oleh karena itu, biasanya memerlukan tenaga karena dilakukan oleh otot-otot yang lebih besar. Pengembangan gerakan motorik kasar juga memerlukan koordinasi kelompok otot-otot anak yang tertentu yang dapat membuat mereka dapat meloncat, memanjat, berlari, menaiki sepeda roda tiga, serta berdiri dengan satu kaki. bahkan ada juga anak-anak yang melakukan hal -hal lebih sulit. Seperti jungkir balik dan bermain sepatu roda. Oleh sebab itu biasanya anak belajar gerakan motorik kasar di luar kelas atau luar ruangan.

Guna merangsang motorik kasar anak usia dini (Sujiono, 2005) dapat dilakukn dengan melatih anak untuk meloncat, memanjat, memeras, bersiul, membuat ekspresi muka senang, sedih, gembira, berlari, berjinjit, berdiri diatas satu kaki, berjalan dietitian dan sebagainya. Gerakan motorik kasar melibatkan aktivitas otot tangan, kaki, dan seluruh tubuh anak. 


\section{Aip Saripudin}

Gerakan ini mengandalkan kematangan dalam koordinasi. Berbagai gerakan motoric kasar yang dicapai anak tentu sangat berguna bagi kehidupannya kelak. Misalnya, anak dibiasakan terampil berlari atau memanjat jika ia sudah lebih besar ia akan senang berolahraga. Untuk melatih gerakan motorik kasar anak dapat dilakukan misalnya, dengan melatih anak berdiri diatas satu kaki. jika anak kurang terampil berdiri di atas satu kakinya berarti penguasaan kemampuan lain, seperti berlari akan terpengaruh karena berarti anak tersebut masih belum dapat mengontrol keseimbangan tubuhnya. Dalam perkembangannya, motorik kasar berkembang lebih dulu dari pada motorik halus. Hal ini dapat terlihat saat anak sudah dapat menggunakan otot-otot kakinya untuk berjalan sebelum ia dapat mengontrol tangan dan jarijarinya untuk menggunting dan meronce.

\section{Gerak Dasar Motorik Kasar pada Anak}

Terdapat tiga macam gerak dasar motorik kasar pada anak usia dini, diantaranya adalah berjalan, berlari dan melompat. Sebagaimana penjelasan sebagai berikut (Maimunah \& Hasan, 2010):

\section{Berjalan}

Pada kemampuan motorik kasar fase ini, yang harus diberikan stimulasi adalah kemampuan berdiri, berjalan kedepan, berjalan kebelakang, berjalan berjingkat, melompat atau meloncat, berlari, berdiri satu kaki, menendang bola. Berjaan seharusnya dikuasai anak saat berusia satu tahun, sedangkan berdiri satu kaki dikuasai naka saat dia berusia dua tahun. Untuk kemampuan berjalan perkembangan yang dikuatkan adalah keseimbangan dalam berdiri. Hal ini berarti anak tidak hanya dituntut untuk sekedar berdiri, tetapi juga berdiri dalam wakt yang lama, dan ini berkaitan dengan lamanya otot kaki bekerja. Bila perkembangan jalan tidak di kembangkan dengan baik, maka anak akan mengalami gangguan keseimbangan. Anak cenderung kurang percaya diri dan ia selalu menghindari aktivitas yang melibatkan keseimbangan seperti main ayunan, seluncur, dan lain - lain.

\section{Berlari}

Perkembangan lari akan mempengaruhi perkembangan lompat, lempar dan kemampuan konsentrasi anak. Pada tugas kkeseimbangan ini, diperlukan keseimbangan tubuh, kecepatan gerak kaki, ketepatan empat pola kaki, bertumpu pada tumit (beel strike), telapak kaki mengangkat dan bertumpu pada ujung - ujung jari kaki (toe off), kaki berayun (swing), dan mengayun kaki menapak pada alas (landing), serta perencanaan gerak (motor planning). Jika perkembangan lari tidak dikembangkan dengan baik, anak akan bermasalah pada keseimbangannya, seperti mudah lelah dalam beraktivitas fisik, sulit berkonsentrasi, cenderung menghindari tugas - tugas yang melibatkan konsentrasi dan aktivitas yang 
Aip Saripudin

melibatkan mental seperti memasng puzzle, tidak mau mendengarkan saat guru sedang bercerita dan lain sebagainya.

3. Melompat

Kemampuan dasar yang harus dimiliki anak pada fase melompat adalah keseimbangan yang baik, kemampuan koordinasi motorik, dan perencanaan gerak ( motor planning ). Jika anak tidak kuat dalam pengembangan melompat, biasanya akan menghadapi kesulitan dalam sebuah perencanaan tugas yang terorganisasi (tugas-tugas yang membutuhkan kemampuan motor planning).

\section{Unsur-Unsur Ketrampilan Motorik Kasar}

Pada dasarnya keterampilan motorik orang berbeda - beda tergantung pada banyaknya gerakkan yang dikuasainya. Memperhatikan pendapat di atas dapat disimpulkan bahwa ketrampilan motorik kasar unsur - unsurnya identik dengan unsur yang dikembangkan dalam kebugaran jasmani pada umumnya. Hal ini sesuai pendapat Depdiknas (2008) bahwa perkembangan motorik merupakan perkembangan unsur kematangan dan pengendalian gerak tubuh, keterampilan dan kontrol motorik.

Menurut bambang (Sujiono, 2005) menyatakan bahwa unsur - unsur kebugaran jasmani meliputi :

a. Kekuatan, Kekuatan (strength) adalaha kemampuan seseorang untuk membangkitkan tegangan (tension) terhadap suatu tahanan (resisten). Derajat kekuatan otot tersebut pada umumnya berbeda untuk setiap orang. Kekuatan otot dapat dikembangkan melalui latihan - latihan melawan tahanan yang ditingkatkan sedikit demi sedikit. Kekuuatan merupakan hasilkerja otot yang berupa kemampuan untuk mengangkat, menjinjing, menahan, mendorong, atau menarik beban. Semakin besar penampang lintang otot, akan semakin besar pula kekuatan yang dihasilkan dari kerja otot tersebut. Sebaliknya, semakin kecil penampang lintangnya, akan semakin kecil pula kekuatan yang dihasilkan.

b. Daya Tahan, Daya Tahan (endurance) adalah kemampuan tubuh mensuplai oksigen yang diperlukan untuk melakukan suatu kegiatan. Apabila seseorang melakukan kegiatan latihan khusus untuk memperbaiki daya tahan tubuhnya maka akan terjati peningkatan kapiler - kapiler jaringan otot. Daya tahan otot ( muscular endurance) adalah kemampuan otot atau sekelompok otot untuk bertahan melakukan suatu kegiatan dalam waktu yang lama. Daya tahan jantung ( cardiovascular endurance ) adalah kemampuan seseorang untuk mempertahankan suatu kegiatan yang membutuhkan tahanan dalam waktu yang lama. Daya tahan tubuh diberikan dalam bentuk kegiatan lari perlahan atau jalan cepat dengan jarak agak jauh, daya tahan otot dapat diberikan dengan latihan - 
Aip Saripudin

latihan seperti lompat tali, lari naik tangga, dorong mendorong, tarik menarik, yang dilakukan dengan berulang - ulang dalam waktu yang relative lama.

c. Kecepatan, Dapat diberikan dengan kegiatan latihan yang serba cepat, seperti lari dengan jarakyang pendek.

d. Kelincahan, Kelincahan ( agility ) adalah kemampuan seseorang untuk bergerak secara cepat. Komponen kelincahan adalah sebagai berikut: 1) Melakukan gerak arah perubahan secara cepat, 2) Berlari cepat, kemudian berhenti secara mendadak, 3) Kecepatan bereaksi. Menurut Mahendra yang mengutip Gobont (1989) kecepatan bergerak ditentukan oleh faktor - faktor berikut : 1) Frekuensi rangsang, yang tergantung pada kemampuan, kebutuhan, tekad, serta mobilitas syaraf, 2) Kecepatan kontraksi otot, 3) Tingkat tonasi gerak, 4) Keadaan kualitas otot tertentu, misalnya kekuatan otot serta tenaga ledak otot ( muscle power ).

e. Kelenturan, Kelenturan (flexibility) adalah kualitas yang memungkinkan suatu segmen bergerak semaksimal mungkin menurut kemungkinan rentang geraknya ( range of movement ). Fleksibilitas seseorang ditentukan oleh kemampuan gerak dari sendi - sendi. Makin luas ruang gerak sendi - sendi semakin baik fleksibilitas seseorang.

f. Koordinasi, Koordinasi merupakan kemampuan yang mencakup dua atau lebih kemampuan perseptual pola - pola gerak. Termasuk kemampuan gerak koordinasi sebagai berikut (1) Koordinasi mata dan tangan, yang berhubungan dengan kemampuan memilih suatu objek dan mengkoordinasikannya ( objekyang dilihat dengan gerakan - gerakan yang diatur ). Contohnya adalah dalam permainan menangkap bola. Koordinasi mata dan tangan menghendaki pengamatan yang tepat. (2) Koordinasi mata dan kaki, yang berhubungan dengan kemampuan mmelakukan suatu gerak berdasarkan penglihatan dan gerak anggota badan bagian bawah. Misalnya : Menendang bola.

g. Ketepatan, Kegiatan yang dapat dilakukan pada anak usia TK. Misalnya : melempar bola kecil kesasaran tertentu atau memasukkan bola kedalam keranjang.

h. Keseimbangan, Keseimbangan dapat diklasifikasikan menjadi 2 macam, yaitu keseimbangan statis dan keseimbangan dinamik. Keseimbangan statik adalah kemampuan mempertahankan posisi tubuh tertentu untuk tidak bergoyang atau roboh, sedangkan keseimbangan dinamik adalah kemampuan untuk mempertahankan tubuh agar tidak jatuh pada saat sedang melakukan gerakan.

\section{Pembagian Keterampilan Motorik Kasar}

Menurut Magill Richard A (A., 1989) berdasarkan kecermatan dalam melakukan gerakan, keterampilan di bagi menjadi dua yaitu motorik kasar dan motorik halus. Keterampilan motorik kasar sebagai berikut sebagai berikut : Keterampilan motorik kasar 
Aip Saripudin

(Gross Motor Skill) merupakan keterampilan gerak yang menggunakan otot-otot besar. Tujuan akan kecermatan gerak bukan merupakan suatu hal penting, akan tetapi koordinasi yang halus dalam gerakan adalah hal yang penting untuk penampilan keterampilan dalam tugas ini. Contoh dari keterampilan gerak kasar yaitu berjalan, melompat, melempar dan meloncat. Pengertian yang senada diungkapkan oleh Bambang Sujiono (2007: 12) menyatakan bahwa motorik kasar ialah gerakan fisik yang melibatkan otot-otot besar seperti otot lengan, otot kaki, dan otot leher. Secara alamiah seiring dengan peningkatan dan bertambahnya usia anak lima tahun samapi dewasa akan diikuti bertambahnya keterampilan gerak motorik anak. Hurlock (1978) menyatakan bahwa pada anak usia 4 sampai 5 tahun pertama kehidupan pasca lahir anak dapat mengendalikan gerakan kasar. Gerakan tersebut melibatkan bagian badan yang luas dan digunakan untuk berjalan, loncat, lompat, lari dan sebagainya. Setelah 5 tahun terjadi perkembangan yang besar dalam pengendalian koordinasi yang lebih baik yang melibatkan kelompok otot yang lebih kuat.

Keterampilan motorik adalah keterampilan seseorang dalam menampilkan gerak sampai gerak lebih komplek. Keterampilan motorik tersebut merupakan suatu keterampilan umum seseorang yang berkaitan dengan berbagai keterampilan atau tugas gerak (Sukadiyanto, 1997). Dengan demikian keterampilan motorik adalah keterampilan gerak seseorang dalam melakukan penunjang segala kegiatan terutama olahraga. Di dalam buku yang terbitkan Depdiknas (2002) bahwa prinsip perkembangan motorik anak prasekolah ialah perubahan baik fisik maupun psikis, sesuai dengan masa pertumbuhannya. Perkembangan motorik sangat dipengaruhi oleh gizi, status kesehatan, dan perlakuan motorik sesuai dengan masa perkembangan.

\section{Faktor-faktor yang Mempengaruhi Perkembangan Motorik Kasar}

Pencapaian suatu keterampilan dianggap dipengaruhi oleh banyak faktor. Diikuti beberapa variasi yang mempengaruhi pola perkembangan motorik anak. menurut Depdiknas (2008) perkembangan motorik sangat dipengaruhi oleh gizi, status kesehatan, dan perlakuan motorik yang sesuai dengan masa perkembangannya. Lebih lamjut dikatakan bahwa tahapan perkembangan motorik anak pra sekolah yaitu tahap verbal kognitif, tahap asosiatif, dan tahap otomatisasi. Menurut Mahendra (1998) menyatakan bahwa faktor-faktor yang mempengaruhi keterampilan motorik anak yaitu (1) faktor proses belajar, (2) faktor pribadi dan (3) faktor situasional (lingkungan). Ketiga faktor inilah yang diyakini telah menjadi penentu utama dari tercapainya tidaknya keterampilan yang dipelajari.

Adapun faktor-faktor yang mempengaruhi perkembagan motorik juga dikemukakan oleh Diah (Rahmatia, 2008) yang menyatakan bahwa perkembangan fisik anak dipengaruhi oleh faktor keturunan dalam keluarga, jenis kelamin, gizi, kesehatan, status sosial, ekonomi, 
Aip Saripudin

dan gangguan emosional. Lebih lanjut dijelaskan bahwa tubuh secara langsung akan menentukan keterampilan gerak anak, dan secara tidak langsung akan mempengaruhi cara anak dalam memandang dirinya sendiri dan memandang orang lain. Menurut Bambang Sujiono (2007) menyatakan bahwa beberapa faktor yang mempengaruhi perkembangan keterampilan gerak yaitu faktor tampilan dan faktor lingkungan. Lebih lanjut dijelaskan bahwa faktor tampilan paling sering berpengaruh pada keterampilan gerak tertentu, faktor tampilan dapat berupa ukuran tubuh, pertumbuhan fisik, kekuatan, danberat tubuh serta sistem syaraf. Hurlock (1978) mengemukakan bahwa ada beberapa faktor yang mempengaruhi perbedaan keterampilan motorik diantaranya pengaruh keluarga, gizi, gangguan emosional, jenis kelamin, suku bangsa, kecerdasan, status sosial ekonomi, kesehatan, fungsi endokrin, pengaruh pra lahir, dan pengaruh tubuh.

Lebih kompleks dikemukakan oleh Sugianto dan Sujarwo (1991) bahwa ada sembilan macam yang dapat mempengaruhi pertumbuhan fisisk anak sejak lahir diantaranya keturunan, pengaruh gizi, pengaruh perbedaan suku, pengaruh musim dan iklim, pengaruh penyakit, pengaruh himpitan psikososial, pengaruh urbanisasi, pengaruh jumlah keluarga dan status sosial ekonomi, dan kecenderungan seluler. Dari berbagai pendapat diatas dapat disimpulkan bahwa faktor-faktor yang mempengaruhi perkembangan motorik anak yaitu faktor proses belajar, dalam hal ini proses belajar yang harus diciptakan adalah dilakukan berdasarkan tahapan-tahapan yang digariskan oleh teori belajar yang diyakini kebenarannya serta dipilih berdasarkan nilai manfaatnya. Faktor pribadi merupakan individu yang berbeda-beda, baik fisik, mental sosial, maupun kemampuankemampuannya. Faktor situasional merupakan faktor yang mampu memberikan perubahan makna serta situasi pada kondisi pembelajaran.

\section{B. PEMBAHASAN}

Kemampuan motorik kasar merupakan salah satu aspek yang penting untuk perkembangan dan pertumbuhan anak. Pertumbuhan anak usia dini sangat bergantung terhadap kemampuan motorik kasar yang dilakukannya. Menurut Fikriyati (2013) kemampuan motorik sangat erat kaitannya dengan perkembangan pengendalian gerakan tubuh melalui kegiatan yang terkoordinir antara susunan syaraf, otot, otak, dan spinal card. Motorik kasar didefinisikan sebagai gerakan tubuh yang menggunakan otot-otot besar atau sebagian besar atau seluruh anggotatubuh yang dipengaruhi oleh kematangan anak itu sendiri. Hal serupa dikemukakan oleh Gallahue (1989) bahwa kemampuan motorik kasar sangat berhubungan dengan kerja otot-otot besar pada tubuh manusia. Kemampuan ini biasanya dilakukan oleh anak untuk melakukan aktifitas olahraga. Kemampuan ini berhubungan dengan kecakapan anak dalam melakukan berbagai gerakan. Gallahue membagi kemampuan 


\section{Aip Saripudin}

motorik dalam tiga kategori, yaitu: 1) kemampuan Lokomotor, 2) Kemampuan Nonlokomotor, dan 3) Kemampuan Manipulatif.

Salah satu kemampuan motorik yang sedang berkembang pesat saat usia dini yaitu kemampuan motorik. Terdapat beberapa penyebab yang mempengaruhi perkembangan motorik anak usia dini yakni faktor genetic atau keturunan, faktor asupan gizi, faktor pola pengasuhan orangtua serta latar belakang budaya. Dengan demikian tentunya perkembangan motorik anak akan berbeda-beda sesuai dengan faktor penyebab perkembangannya serta faktor lingkungan yang mempengaruhinya. Perkembangan motorik terbagi menjadi dua yaitu motorik kasar dan motorik halus. Motorik kasar memerlukan kordinasi otot-otot besar yang dapat membuat mereka melompat, memanjat, berlari, menaiki sepeda, menaiki tangga dan lain sebagainya. Sementra motorik halus memerlukan kordinsi otot-otot kecil yakni tangan dan mata seperti menggambar, menulis, menggunting, menali sepatu dan lain sebagainya, semakin baiknya gerakan motorik, maka membuat anak dapat berkreasi dan kreatif. Begitu pula sebaliknya anak yang belum matang motoriknya maka akan cenderung diam dan tidak bergairah dalam bermain bersama teman sebayanya. Untuk mengoptimalkan motorik kasar maupun halus, maka diperlukan peran-peran dari keluarga dalam mengembangkannya. Peran keluarga sangat penting, sehingga anak dapat mencapai keterampilannya sesuai dengan usia perkembangannya (Aip Saripudin, Maret 2016).

\section{SIMPULAN}

Tumbuh kembang anak dapat dipengaruhi oleh beberapa faktor baik internal maupun eksternal anak. Pertumbuhan dan Perkembangan melibatkan perubahan yang terjadi pada anak yakni terjadi secara bersamaan yang disertai dengan perubahan fungsi-fungsi lainnya. Seperti halnya dalam perkembangan motorik kasar tentunya disertai dengan perubahan pada organ lain yang menyertainya. Perubahan-perubahan motorik yang terjadi meliputi perubahan ukuran tubuh secara umum, perubahan proporsi tubuh, berubahnya ciri-ciri lama dan timbulnya ciri-ciri baru sebagai tanda kematangan suatu organ tubuh tertentu. Pada dasarnya perkembangan awal itu akan menentukan perkembangan selanjutnya, sehingga penting perkembangan motorik terstimulasi sejak dini. Seseorang tidak akan melewati satu tahap perkembangan sebelum dia melewati tahapan sebelumnya. Karena itu perkembangan awal merupakan masa kritis karena akan menentukan perkembangan selanjutnya. Perkembangan juga memiliki tahap yang berurutan, tahap ini di lalui seorang anak mengikuti pola yang teratur dan berurutan. 
Aip Saripudin

\section{DAFTAR PUSTAKA}

B. Suhartini, \& Sumarjo. (2000). Perkembangan Motorik.

Depdiknas. (2000). Pengembangan Motorik. Jakarta.

Depdiknas. (2003). Undang-Undang N0.20 Tentang Sisdiknas. Jakarta: Dikdasmen.

Depdiknas. (2008). Fungsi Perkembangan Motorik. Jakarta: Dikdasmen.

Evita. (2013). Meningkatkan Motorik Kasar Anak Melalui Oermainan Egrang Bathok Kelapa Pada Anak Kelommpok B di TK ABA Banjarharjo II Kalibawang Kulonprogo.

Febriyani, E. (2015). In Upaya Meningkatkan Pengembangan Motorik Kasar (Melompat) Anak Melalui Permainan Lompat Tali Pada Kelompok B TK Al-Hidayah Palaosan.

Hidayanti, M. (2013). Peningkatan Kemampuan Motorik Kasar Anak Melalui Permainan Bakiak. Jurnal Pendidikan Usia Dini, 196-197.

Hurlock, E. B. (1978). Perkembangan Anak. Erlangga.

Lina, N. (2016). Kemampuan Mengenal Suku Kata Awal anak TK Kelompok B di Gugus PAUD 4 Tirtomartani Kecamatan Kalasan.

Maimunah, \& Hasan. (2010). Pendidikan Anak Usia Dini. Yogyakarta: Diva Press.

Aip Saripudin. (2016). Peran Keluarga Dalam Mengoptimalkan Motorik Kasar Anak Usia Dini, 1.

Mursyid, M. (2015). Pengembangan Pembelajaran PAUD. Bandung: PT. Remaja Psdakarya.

Nurlela. (2016). In Peningkatan Motorik Kasar Anak Melalui Permainan Tradisional Yeye Pada Anak Kelompok B Di RA Baiturrahman Kecamatan Kedawung Kabupaten Cirebon.

PERMENDIKBUD.(2014). In Peraturan Mentri Pendidikan dan Kebudayaan Republik Indonesia Nomor 146 Tahun 2014 Tentang Kurikulum 2013 Pendidikan Anak Usia Dini.

Puspitowati, \& Sri Hartini. (2012). Jurnal Upaya Meningkatkan Motorik Kasar Anak Melalui Permainan Tradisional Lompat Tali Kelompok B di Tk Pertiwi Sribit Delanggu Klaten Tahun Ajaran 2012/2013. Surakarta: Universitas Muhammadiyah Surakarta.

Puspitowati, S. P. (2012). In Upaya Maningkatkan Motorik Kasar Anak Melalui Permainan Tradisional Lompat Tali Pada Kelompok B Di TK Pertiwi Sribit Delanggu Klaten.

Rahmatia, D. (2008). Bagaimana Pertumbuhan dan Perkembangan Manusia. Bandung: Shakti adiluhung.

Sari, P. I. (2015). In Upaya Meningkatkan Motorik Kasar Anak Melalui Lompat Tali Pada Kelompok A Di TK Aba Ngabean I Tempel Sleman.

Sugiyono. (2007). Metode Penelitian Pendidikan Pendekatan Kuantitatif, Kualitatif, dan $R$ \& 
Aip Saripudin

D. Bandung: Alfabeta.

Suhadinet.wordpress.com. (2009, Juni). Langkah-langkah PTK Menurut Kemmis dan McTaggart.

Sujiono, B. (2005). Metode Pengembangan Fisik. Jakarta: Universitas Terbuka.

Sukadiyanto. (1997). Penentuan Tahap Kemampuan Motorik Anak SD.Edisi I TH III April 1997 Majalah Olahraga. Yogyakarta: FPOK.

Sukamti, E. R. (2007). Diktat Perkembangan Motorik. Yogyakarta: Fakultas Ilmu Keolahragaan Universitas Negeri Yogyakarta.

Suyanto, S. (2005). Konsep Dasar Anak Usia Dini. yogyakarta: FIP Universitas Negeri Yogyakarta.

Thobroni M, Mumtaz, \& Khoiruzul. (2014). Mendongkrak Kecerdasan anak Melalui Bermain dan Permainan. Yogyakarta: KATAHATI.

Yuliani. (2010). Konsep Dasar Pendidikan Anak Usia Dini. Jakarta: Indeks. 